\title{
Five-phase induction motor drive for electric vehicle with high gain switched-inductor quasi impedance source inverter
}

\author{
Yaramasu Suri Babu ${ }^{1,2}$, Koritala Chandra Sekhar ${ }^{2}$ \\ ${ }^{1}$ ANU College of Engineering and Technology, Acharya Nagarjuna University, Guntur, India \\ ${ }^{2}$ RVR \& JC College of Engineering, Guntur, India
}

\begin{tabular}{l} 
Article Info \\
\hline Article history: \\
Received Jul 19, 2021 \\
Revised Jan 25, 2022 \\
Accepted Feb 1, 2022 \\
\hline
\end{tabular}

Keywords:

Five-phase induction motor

High gain inverter

Quasi-impedance source

inverter (qZSI)

Solar photovsoltaic

Switched-inductor

\begin{abstract}
Switched-inductor quasi-impedance source inverter (SL-qZSI) with high gain fed five-phase induction motor drive for electric vehicle (EV) applications is proposed in this paper. Multi-phase electric machines have been predicted for application where the entire system should have better reliability and demanded power per phase is low especially for autonomous applications like EVs. To supply variable voltage and frequency to multiphase machines, multi-phase inverters are required. SL-qZSI offers enhanced boost capability with respect to traditional impedance source converters by inserting three diodes and only one inductor to the basic quasiimpedance source inverter (qZSI). Also, SL-qZSI offers withstanding capability during voltage dip results line harmonics are diminished; enhances reliability of inverter; and extended output voltage range. The key idea of this paper is to design and develop a high performance and highly reliable SL-qZSI fed five-phase Induction Motor drive and validate the proposed system depends on results of Simulation with the help of MATLAB; these findings were comparable to the similar type of existing converters. We can notice from the performance analysis of the proposed system that it can provide enhanced voltage boosting capability and proved that it has significant potential for the suggested multi-phase variable speed drive (VSD) system.
\end{abstract}

This is an open access article under the $\underline{C C B Y-S A}$ license.

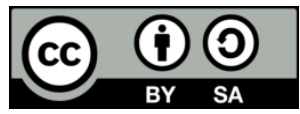

\section{Corresponding Author:}

Yaramasu Suri Babu

Department of Electrical and Electronics Engineering, Acharya Nagarjuna University College of

Engineering and Technology

Guntur, Andhra Pradesh, India

Email: ysuribabu@gmail.com

\section{INTRODUCTION}

In the past few years, the benefits offered by the three-phase induction motor made it apt for the application of adjustable speed drive (ASD) [1]. Nevertheless, the perturbed operation of the three-phase machine has to be taken into account during the faulty condition. In such situation modification of hardware for the drive system is expensive [2]. These days, the focus is grabbed by multi-phase induction motors (IM) because of their added benefits compared to the deep-rooted three-phase machines [3]. Benefits offered by it are better torque density, reduced power rating of switches, decreased pulsations in torque, improved efficiency, harmonics get reduced in DC link current, [4]-[5]. The most attractive feature of multi-phase motor is inherent fault-tolerant capability without any requirement of extra hardware [6]. Hence multi-phase machines are employed in applications where the requirement of high power and safety is essential such as ship propulsion, electric vehicle (EV), electric aircraft, hybrid electric vehicles (HEVs) [7], [8]. 
Five-phase machines are commonly investigated and described in many documents since, among multi-phase machines, five-phase machines provide many essential features relative to remaining multi-phase machines [9]. In this paper, for multi-phase motor drives, speed control techniques are similar to that of traditional 3-phase machines; V/f control is implemented. The constant V/f control technique provides ease in the implementation, comparatively better efficiency, the excellent performance of impedance source inverter (ZSI), low current total harmonic disorder (THD). However, the transient and response for low speed are worse. Thus, it is applied to the system where the sluggish response is not a concern [10].

Generally, to supply a five-phase induction machine, a five-phase inverter is required; usually, the conventional two-level inverter is the solution. Nevertheless, it is subjected to many constraints and disadvantages: minimum output voltage is attained, dips in voltage suspends the VSD system, and leads to abandonment of few loads due to the absence of withstanding capability; as a result, it is not adequate to sensitive loads [11]. Output voltage controls the output power because the output is related to the square of the voltage. So the consequence is dimensions of the motor increases, which is unwanted for the desired power rating. VSD industry enables the enhancement of ride-through with various alternatives like fly-back converters and energy storage with boost converters [12]. Instead, these alternatives are not feasible due to price, size, and intricacy. With voltage source inverter (VSI) topology, we have to compromise for reliability due to i) at low speeds dead time causes distortion; ii) premature failure of bearings due to shaft current, which is produced by common mode voltages (CMV).

To surpass the drawbacks in the classical inverters, conversion of power with the capabilities of both step-down and step-up in a single-stage, it suggested ZSI [13]. The voltage at the output terminals is boosted in the shoot-through (ST) mode, which is unique feature in ZSI different from VSI. Due to this unique feature, ZSI offers a low cost, single-stage, an easier system for applications of fuel cell and solar PV. In a leg, power switches are turned ON concurrently to avoid the dead time. In the direction of varying the magnitude of output voltage in a extensive range shoot through interval should be regulated. This quality significantly decreases the distortion at output terminals and enhances reliability. Because of this quality, ZSI settles in applications where safety and better operational reliability has to be guaranteed. The advantages of ZSI with the multi-phase machine are verified using classical ZSI implemented with five-phase [14] and sixphase systems [15]. However, limitation of ZSI is discontinuous input current. To maintain continuous current then a filter is required at the DC source side [16]-[18]. In remaining impedance network topologies, the latest type of quasi ZSIs (qZSI) has been proposed that dominates the equivalent of basic ZSI. The significant advantage provided by qZSI is a low rating of passive components.

In the traditional VSI design, we should trade-off the reliability of the VSD system. Since the applications of solar PV based system like EV or HEV are almost stand-alone, so, it requires a great reliable system. Even though the multi-phase machine can afford reliable operation as it is essentially fault-tolerant, we may try to further enhancement in device reliability by selecting the best converters from the converter side. Various feasible methods are there for equating the load voltage (high voltage side) requirement from source (low voltage side): i) connecting a series combination of energy sources such as either solar cells, fuel cells or batteries to achieve the required voltage, ii) arranging two or more low voltage gain DC-DC boost converters in cascaded form, and iii) combination of a DC-DC boost converter along with a transformer. Among these are neither reliable nor economical. Using high boost factor converters are the best possible method to equate the difference in source voltage. Moreover, additional enhancement in the reliability of the VSD system is achieved by these high gain converters. In [19]-[21], the focus mainly on enhancing the boost factor of ZSI by introducing diodes, capacitors, and inductors to the Z-network, as explained in [19] and [20]. A transformer is used instead of two inductors to achieve high voltage raise [21]. In addition to this, the high gain in cascade and transformer-less configurations is achieved by using hybrid designs, and voltage multiplier cells [22]-[23] with the application of capacitors and switched-inductor. The drawback of boost limitation in the primary ZSI is surpassed with the help of a combined design structure of basic ZSI and switched-inductor. This entire design is known as the switched inductor ZSI (SL-ZSI), which delivers high conversion boost voltage.

Nowadays, in power electronics converters, SL-qZSI is the best topology [24] exclusively with interesting properties like: i) offers withstanding capability without any changes in circuit, ii) improved power factor, and iii) decreased magnitude of common mode voltages (CMV) and current harmonics. In contrast to remaining VSDs [25]-[27] fed by high gain ZSI, VSD systems fed with SL-qZSI have the aforementioned capabilities and better reliability. A switched inductor is inserted to the qZSI topology to produce a new inverter coined as SL-qZSI. Suggested five-phase SL-qZSI is implemented to fed five-phase induction motor. Relative to remaining high gain boost converters, SL-qZSI provides various advantages like dc supply having common ground, suppressing inrush current during start-up. So far, no literature on the performance study of a five-phase IM drive with SL-qZSI has been presented. Investigating the efficiency of the suggested system is stepping ahead towards suitability for applications where the system requires high reliability.

Int J Pow Elec \& Dri Syst, Vol. 13, No. 1, March 2022: 411-422 
Therefore, the paper attempts to fill the gap by investigating the five-phase induction motor driven by the SL-qZSI. This paper aims to unite the benefits of both the SL-qZSI and five-phase machines. The suggested five-phase VSD system driven by the SL-qZSI provides improved reliability and transient response, efficiency. The results obtained from the simulation are evaluated for assessing the system performance. Here, the paper introduces an innovative high gain switched-inductor quasi impedance source inverter (SL-qZSI) fed five-phase IM drive suitable for EV that fulfills nearly all of the aforesaid features. In the section 2, described the proposed system, the simulation results are presented and analyzed in section 3. Conclusion of this effort is presented in section 4

\section{PROPOSED SL-qZSI FED INDUCTION MOTOR}

\subsection{Modeling of five-phase phase induction motor}

Consider the phase angle displacement between any two adjacent phases of a five-phase IM. The below assumptions are taken into account for deriving a mathematical model of a five-phase machine.

- In a winding, the MMF produced is distributed sinusoidal along the diameter of the air gap.

- The air gap is constant.

- The saturation of the main flux can be ignored since the iron core has a linear B-H curve.

- Iron core losses can be ignored.

- Resistance and inductance of the winding are constant.

In accordance with the winding transformation ratio, assuming that rotor winding is talk about the stator winding. Flux linkage, rotor, and stator voltage equations are conveyed as:

$$
\left.\begin{array}{l}
\underline{v}_{a b c d e}^{r}=\underline{R}_{r} \underline{l}_{a b c d e}^{r}+\frac{d \underline{\psi}_{a b c d e}^{r}}{d t} \\
\underline{\psi}_{a b c d e}^{r}=\underline{L}_{r} \underline{l}_{a b c d e}^{r}+\underline{L}_{r s} \underline{l}_{a b c d e}^{s}
\end{array}\right\}
$$

The voltage, current, flux linkages in (1) and (2) can be defined as:

$$
\left.\begin{array}{l}
\underline{v}_{a b c d e}^{s}=\left[v_{a s} v_{b s} v_{c s} v_{d s} v_{e s}\right]^{T} \\
\underline{\underline{l}}_{a b c d e}^{s}=\left[i_{a s} i_{b s} i_{c s} i_{d s} i_{e s}\right]^{T} \\
\underline{\psi}_{a b c d e}^{s}=\left[\psi_{a s} \psi_{b s} \psi_{c s} \psi_{d s} \psi_{e s}\right]^{T} \\
\underline{v}_{a b c d e}^{r}=\left[v_{a r} v_{b r} v_{c r} v_{d r} v_{e r}\right]^{T} \\
\underline{\underline{l}}_{a b c d e}^{r}=\left[i_{a r} i_{b r} i_{c r} i_{d r} i_{e r}\right]^{T} \\
\underline{\psi}_{a b c d e}^{r}=\left[\psi_{a r} \psi_{b r} \psi_{c r} \psi_{d r} \psi_{e r}\right]^{T}
\end{array}\right\}
$$

Stator and rotor inductance matrices are given as:

$$
\begin{aligned}
\underline{L}_{s} & =\left[\begin{array}{ccccc}
L_{l s}+M & M \cos \alpha & M \cos 2 \alpha & M \cos 2 \alpha & M \cos \alpha \\
M \cos \alpha & L_{l s}+M & M \cos \alpha & M \cos 2 \alpha & M \cos 2 \alpha \\
M \cos 2 \alpha & M \cos \alpha & L_{l s}+M & M \cos \alpha & M \cos 2 \alpha \\
M \cos 2 \alpha & M \cos 2 \alpha & M \cos \alpha & L_{l s}+M & M \cos \alpha \\
M \cos \alpha & M \cos 2 \alpha & M \cos 2 \alpha & M \cos \alpha & L_{l s}+M
\end{array}\right] \\
\underline{L}_{r} & =\left[\begin{array}{ccccc}
L_{l s}+M & M \cos \alpha & M \cos 2 \alpha & M \cos 2 \alpha & M \cos \alpha \\
M \cos \alpha & L_{l s}+M & M \cos \alpha & M \cos 2 \alpha & M \cos 2 \alpha \\
M \cos 2 \alpha & M \cos \alpha & L_{l s}+M & M \cos \alpha & M \cos 2 \alpha \\
M \cos 2 \alpha & M \cos 2 \alpha & M \cos \alpha & L_{l s}+M & M \cos \alpha \\
M \cos \alpha & M \cos 2 \alpha & M \cos 2 \alpha & M \cos \alpha & L_{l s}+M
\end{array}\right]
\end{aligned}
$$

Mutual inductance matrix is given by: 


$$
\underline{L}_{s r}=M\left[\begin{array}{ccccc}
\cos \theta & \cos (\theta+\alpha) & \cos (\theta+2 \alpha) & \cos (\theta-2 \alpha) & \cos (\theta-\alpha) \\
\cos (\theta-\alpha) & \cos \theta & \cos (\theta+\alpha) & \cos (\theta+2 \alpha) & \cos (\theta-2 \alpha) \\
\cos (\theta-2 \alpha) & \cos (\theta-\alpha) & \cos \theta & \cos (\theta+\alpha) & \cos (\theta+2 \alpha) \\
\cos (\theta+2 \alpha) & \cos (\theta-2 \alpha) & \cos (\theta-\alpha) & \cos \theta & \cos (\theta+\alpha) \\
\cos (\theta+\alpha) & \cos (\theta+2 \alpha) & \cos (\theta-2 \alpha) & \cos (\theta-\alpha) & \cos \theta
\end{array}\right]
$$

$$
\underline{L}_{r s}=\underline{L}_{s r}^{T}
$$

' $\theta$ 'represents the instantaneous location of the rotor phase ' $a$ ' magnetic axis regarding the stator phase 'a' magnetic axis. In five-phase IM, the matrices of rotor and stator resistances are diagonal in nature, and their order is $5 \times 5$.

Decoupling transformation: to obtain a simplified model, for eliminating the variation of inductances with respect to time, a coordinate conversion is applied. Power invariant form of co-ordinate conversion is employed. Thus, the transformation matrix is applied to five-phase winding of the stator.

$$
\left.\begin{array}{l}
\underline{x}_{n e w}=C \underline{x}_{\text {old }} \\
\underline{x}_{\text {old }}=\underline{C}^{-1} \underline{x}_{n e w}
\end{array}\right\}
$$

Where a transformation matrix of power invariant form is chosen in order that $\underline{C}^{-1}=\underline{C}^{T}$. The decoupling transformation matrix is given as:

$$
\underline{C}=\sqrt{\frac{2}{5}}\left[\begin{array}{ccccc}
1 & \cos \alpha & \cos 2 \alpha & \cos 2 \alpha & \cos \alpha \\
0 & \sin \alpha & \sin 2 \alpha & -\sin 2 \alpha & -\sin \alpha \\
1 & \cos 2 \alpha & \cos 4 \alpha & \cos 4 \alpha & \cos 2 \alpha \\
0 & \sin 2 \alpha & \sin 4 \alpha & \sin 4 \alpha & \sin 2 \alpha \\
\frac{1}{\sqrt{2}} & \frac{1}{\sqrt{2}} & \frac{1}{\sqrt{2}} & \frac{1}{\sqrt{2}} & \frac{1}{\sqrt{2}}
\end{array}\right]
$$

Machine model in a standard arbitrary reference frame:

$$
\left.\begin{array}{l}
\underline{v}_{d q}^{s}=C \underline{v}_{a b c d e}^{s} \underline{l}_{d q}^{s}=C \underline{\underline{\imath}} \underline{\underline{v}}_{a b c d e} \underline{\psi}_{d q}^{s}=\underline{C} \underline{\psi}_{a b c d e}^{s} \\
\underline{v}_{d q}^{r}=\underline{C} \underline{v}_{a b c d e}^{r} \underline{l}_{d q}^{r}=\underline{C} \underline{\imath}_{a b c d e}^{r} \underline{\psi}_{d q}^{r}=\underline{C} \underline{\psi}_{a b c d e}^{r}
\end{array}\right\}
$$

Stator and rotor voltage is shown in (11):

$$
\begin{array}{ll}
v_{d s}=R_{s} i_{d s}-\omega_{a} \psi_{q s}+p \psi_{d s} & v_{d r}=0=R_{r} i_{d r}-\left(\omega_{a}-\omega\right) \psi_{q r}+p \psi_{d r} \\
v_{q s}=R_{s} i_{q s}+\omega_{a} \psi_{d s}+p \psi_{q s} & v_{q r}=0=R_{r} i_{q r}+\left(\omega_{a}-\omega\right) \psi_{d r}+p \psi_{q r} \\
v_{x s}=R_{s} i_{x s}+p \psi_{x s} & v_{x r}=0=R_{r} i_{x r}+p \psi_{x r} \\
v_{y s}=R_{s} i_{y s}+p \psi_{y s} & v_{y 1 r}=0=R_{r} i_{y r}+p \psi_{y r} \\
v_{0 s}=R_{s} i_{0 s}+p \psi_{0 s} & v_{0 r}=0=R_{r} i_{0 r}+p \psi_{0 r}
\end{array}
$$

Flux linkage is shown in (12):

$$
\begin{array}{ll}
\psi_{d s}=\left(L_{l s}+L_{m}\right) i_{d s}+L_{m} i_{d r} & \left.\psi_{d r}=\left(L_{l r}+L_{m}\right) i_{d r}+L_{m} i_{d s}\right) \\
\psi_{q s}=\left(L_{l s}+L_{m}\right) i_{q s}+L_{m} i_{q r} & \psi_{q r}=\left(L_{l r}+L_{m}\right) i_{q r}+L_{m} i_{q s} \\
\psi_{x s}=L_{l s} i_{x s} & \psi_{x r}=L_{l s} i_{x r} \\
\psi_{y s}=L_{l s} i_{y s} & \psi_{y r}=L_{l s} i_{y r} \\
\psi_{0 s}=L_{l s} i_{0 s} & \psi_{0 r}=L_{l s} i_{0 r}
\end{array}
$$

Here again $\mathrm{L}_{\mathrm{m}}=(\mathrm{n} / 2) \mathrm{M}$. 
Torque is shown in (13).

$\left.\begin{array}{l}T_{e}=\frac{n P}{2} M\left[i_{d r} i_{q s}-i_{d s} i_{q r}\right] \\ T_{e}=P L_{m}\left[i_{d r} i_{q S}-i_{d s} i_{q r}\right]\end{array}\right\}$

Under the transformation mechanical equations of rotor motion is constant and is given by (14).

$$
T_{e}-T_{L}=\frac{J}{P} \frac{d \omega}{d t}
$$

Where, ' $P$ ' is the number of poles in machine and ' $J$ ' is inertia.

\subsection{Operation of SL-qZSI [24]}

The power topology of the introduced SL-qZSI fed five-phase IM drive system is appeared in Figure 1. SL-qZSI contains three inductors (viz., $L_{1}, L_{2}, \& L_{3}$ ), four diodes (viz., $D_{i n}, D_{1}, \& D_{2}$ ), and two capacitors (viz., $C_{1} \& C_{2}$ ). Switched Inductor cell comprises of $L_{2}, L_{3}, D_{1}, D_{2}, \& D_{3}$. In contrast to SL-ZSI topology, inrush current flow is eliminated in SL-qZSI topology, since the current flowing through the principle circuit is zero during the start-up; nevertheless, in SL-qZSI the capacitors and inductors still resonate. When compared to the traditional continuous current qZSI, the boost factor in SL-qZSI is enhanced from 1/(1-2D) to $(1+\mathrm{D}) /\left(1-2 \mathrm{D}-\mathrm{D}^{2}\right)$ by adding one inductor and three diodes to its power circuit. Boost factor for basic ZSI and qZSI can be written as:

$$
\begin{aligned}
& B=\frac{V_{P N}}{V_{d c}}=\frac{1}{1-2\left(T_{0} / T\right)}=\frac{1}{1-2 D} \\
& B=\frac{1+\left(T_{0} / T\right)}{1-3\left(T_{0} / T\right)}=\frac{1+D}{1-3 D}
\end{aligned}
$$

where $T_{0}$ is shoot-through interval state, $D=T_{0} / T$ is the duty cycle.

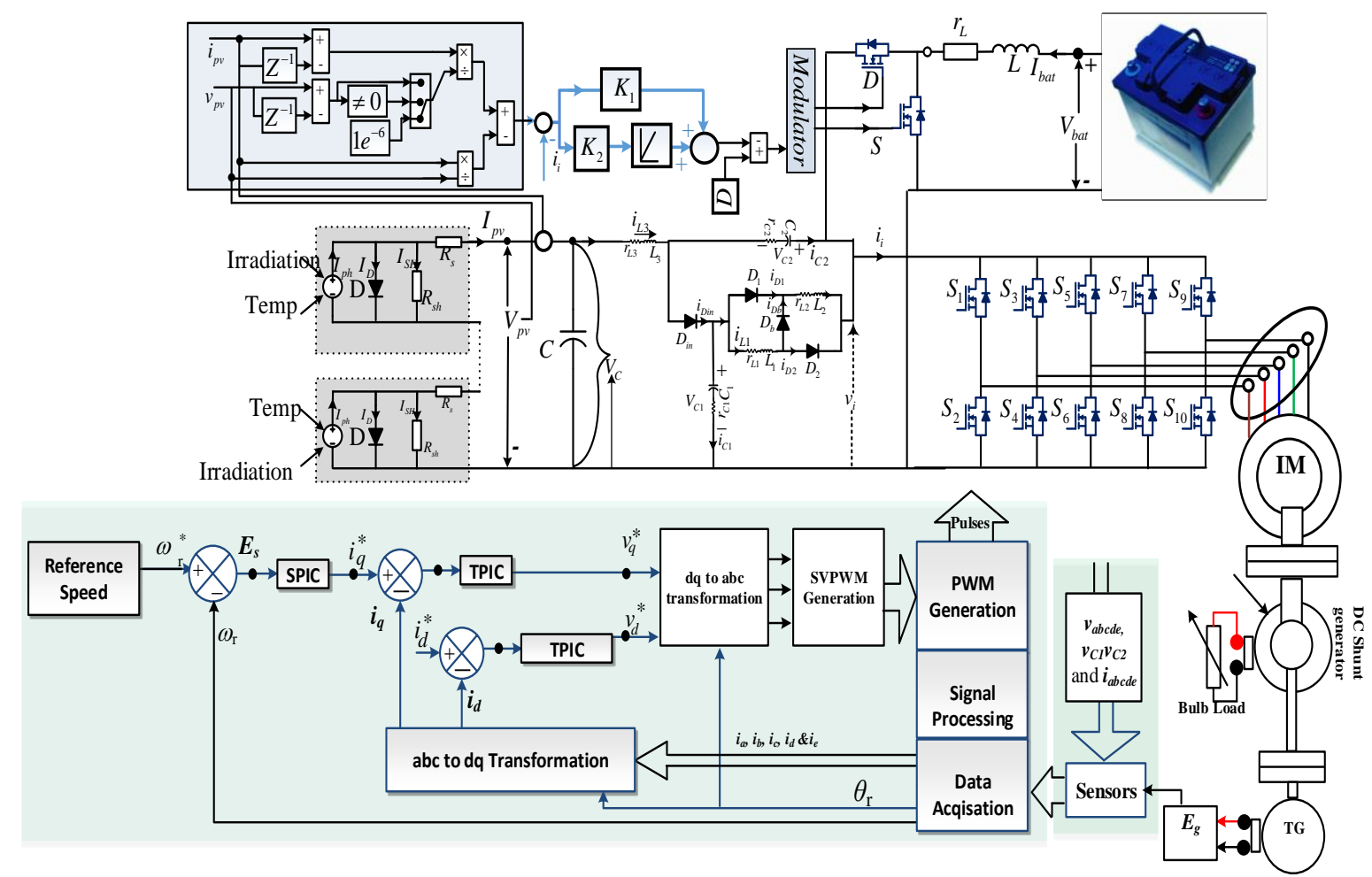

Figure 1. SL-qZSI fed five-phase IM drive 
Circuit analysis: analogous to the traditional ZSI, the five-phase SL-qZSI has typically thirty dynamics and two zero states apart from shoot-through zero states. Hence, the working principle of the suggested is analogous to the conventional ZSI. To simplify the study, the switching states are divided into shoot-through and non-shoot through states (NST). Equivalent circuit diagram of SL-qZSI shown in Figure 2. Figures 2 (a) and 2 (b) shows equivalent circuit during shoot-through state and non-shoot through state respectively. The five-phase SL-qZSI has thirty non-zero and two zero states during non-shoot through condition. In this condition, $D_{i n}$ and $D_{1}$ are conducting whereas $D_{2}$ and $D_{3}$ are open. $L_{2}$ and $L_{3}$ are associated in series. The energy is supplied from DC source to AC circuit by the inductors are of $L_{1}, L_{2}$, and $L_{3}$; during this condition, the capacitors $C_{l} \& C_{2}$ are charged. Also, $V_{L 2 \_n s t}$ and $V_{L 3 \_n s t}$ are voltages across the inductors $L_{2}$ and $L_{3}$, respectively. We get:

$$
\begin{aligned}
& V_{L 1}=V_{C 1}-V_{d c} \\
& V_{L 2}=V_{L 2 \_n s t}=V_{C 2}-V_{L 3 \_n s t} \\
& V_{L 3}=V_{L 3 \_n s t}=V_{C 2}-V_{L 2 \_n s t} \\
& V_{P N}=V_{C 1}+V_{C 2}
\end{aligned}
$$

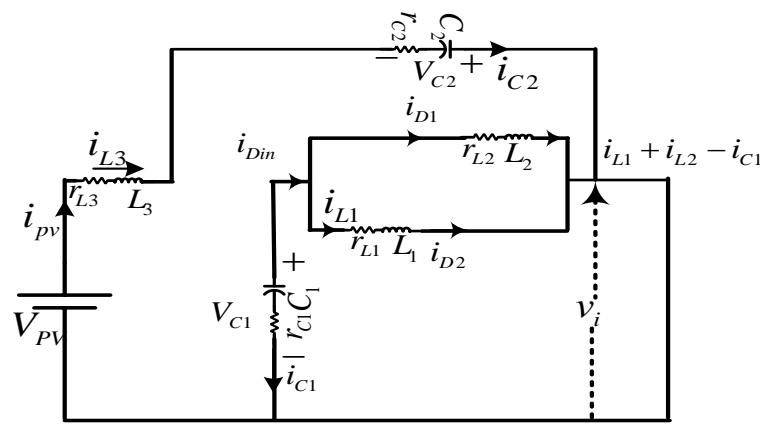

(a)

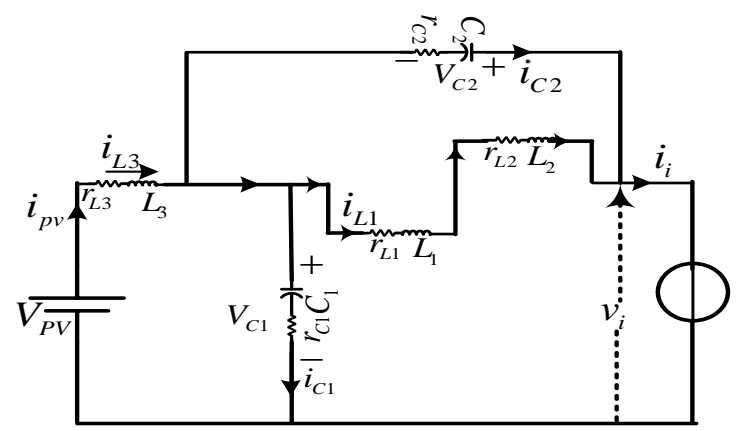

(b)

Figure 2. Equivalent circuit diagram of SL-qZSI (a) shoot-through state (b) non-shoot through state [24]

When both the lower and upper switches of the similar leg are conducting simultaneously, the shootthrough state can be accomplished in an inverter. During shoot-through state, $D_{i n} \& D_{1}$ are open whereas $D_{2} \& D_{3}$ are conducting and inductors $\mathrm{L}_{2} \& \mathrm{~L}_{3}$ are associated in parallel. While the inductors $L_{1}, L_{2} \& L_{3}$ are charging, then the capacitors $\mathrm{C}_{1} \& \mathrm{C}_{2}$ are getting discharged. We get:

$$
\begin{aligned}
& V_{L 1}=-V_{C 2}-V_{d c} \\
& V_{L 2}=V_{L 3}=-V_{c 1}
\end{aligned}
$$

By applying volt-second stability principle to inductors $L_{2} \& L_{3}$ then we get:

$$
\begin{aligned}
& V_{L 2 \_n s t}=V_{L 3 \_n s t}=\frac{-D}{1-D} V_{C 1}+V_{C 2} \\
& V_{C 2}=\frac{2 D}{1-D} V_{C 1}
\end{aligned}
$$

In the same manner, the volt-second stability principle is applied to $L_{1}$ then:

$$
\left.\begin{array}{l}
V_{C 1}=\frac{1-D}{1-2 D-D^{2}} V_{d c} \\
V_{C 2}=\frac{2 D}{1-2 D-D^{2}} V_{d c}
\end{array}\right\}
$$

Substituting (25) in (20) we obtain:

$$
V_{P N}=V_{C 1}+V_{C 2}=\frac{1+D}{1-2 D-D^{2}} V_{d c}=B V_{d c}
$$


Where, $\mathrm{B}$ is defined as the boost factor of the inverter, it is:

$$
B=\frac{1+D}{1-2 D-D^{2}}=\frac{1+\left(T_{0} / T\right)}{1-2\left(T_{0} / T\right)-\left(T_{0} / T\right)^{2}}
$$

Compared to conventional ZSI, the suggested SL-qZSI has superior boost capability, but it has reduced boost capability compared to SL-ZSI.

\subsection{Bidirectional DC-DC converter}

Bi-directional DC to DC converter along with the SL-qZSI is placed in between the DC link and the battery of the inverter, as shown in Figure 1. This bidirectional converter is used as a backup option, and it helps the battery to charge during regenerative braking of the motor. Either of the switches in the bidirectional converter is turned ON to step-down or step-up the voltage. The duty cycle of switches is controlled based on the terminal voltage of the solar PV. If solar energy is low or it is absent, then the battery and bidirectional converter combination maintain constant DC link voltage.

\section{SIMULATION RESULTS}

To approve the exhibition of the proposed structure, solar-powered 1-phase power modulating unit for five-phase IM drive is simulated on the MATLAB/Simulink environs. The determined parameters of simulation are tabularized in the Table 1. In the results section, the simulation results of solar PV voltage and PV current; input voltage and current of the battery; and the output voltages and currents are introduced. It additionally introduces the motor side simulation results, i.e., stator currents and speed of the five-phase IM. DC bus is provided by considering arrangement of PV array of $5 \mathrm{~kW}$ rating with MPPT system in shunt with battery fed bi-directional buck-boost D.C to D.C converter.

Table 1. Simulation parameters

\begin{tabular}{|c|c|c|c|c|c|c|c|}
\hline \multicolumn{2}{|c|}{ Solar PV module specifications } & \multicolumn{2}{|c|}{ Power converter } & \multicolumn{2}{|c|}{$\begin{array}{c}\text { Energy storage power } \\
\text { converter }\end{array}$} & \multicolumn{2}{|c|}{ Induction motor } \\
\hline Parameter & Value & Parameter & Value & Parameter & Value & Parameter & Value \\
\hline Short-circuit current $\left(\mathrm{I}_{\mathrm{SC}}\right)$ & $9.49 \mathrm{~A}$ & Input power & $2 \mathrm{~kW}$ & Input power & $3 \mathrm{~kW}$ & $\begin{array}{l}\text { Output } \\
\text { power }\end{array}$ & $2 \mathrm{~kW}$ \\
\hline Open-circuit voltage $\left(\mathrm{V}_{\mathrm{OC}}\right)$ & $43.20 \mathrm{~V}$ & Input voltage & $200-600 \mathrm{~V}$ & Input voltage & $200 \mathrm{~V}$ & $\begin{array}{l}\text { Rated } \\
\text { speed }\end{array}$ & $1430 \mathrm{rpm}$ \\
\hline $\begin{array}{l}\text { Current at maximum power } \\
\text { point }\left(\mathrm{I}_{\mathrm{MPP}}\right)\end{array}$ & $8.47 \mathrm{~A}$ & Output voltage & 90V@367 Hz & $\begin{array}{l}\text { Output } \\
\text { voltage }\end{array}$ & $200-600 \mathrm{~V}$ & $\begin{array}{l}\text { Rated } \\
\text { torque }\end{array}$ & $10 \mathrm{~N}-\mathrm{m}$ \\
\hline $\begin{array}{l}\text { Voltage at maximum } \\
\text { power point }\left(\mathrm{V}_{\mathrm{MPP}}\right)\end{array}$ & $36 \mathrm{~V}$ & $\begin{array}{l}\text { Switching } \\
\text { frequency }\end{array}$ & $20 \mathrm{kHz}$ & $\begin{array}{l}\text { Switching } \\
\text { frequency }\end{array}$ & $20 \mathrm{kHz}$ & & \\
\hline $\begin{array}{l}\text { Power at maximum power } \\
\text { point }\left(\mathrm{P}_{\mathrm{MPP}}\right)\end{array}$ & $300 \mathrm{~W}$ & & & & & & \\
\hline $\begin{array}{l}\text { No. of series connected } \\
\text { modules }\left(\mathrm{N}_{\mathrm{S}}\right)\end{array}$ & 16 & & & & & & \\
\hline
\end{tabular}

In these simulations, the two instabilities are in the usage of speed of the IM drive and solar irradiation is presented to approve the active performance of the introduced structure. PV temperature stays steady all over the simulation time. From Figure 3 (a) it tends to be seen that at 0.5 -sec, the solar irradiation is reduced, so accordingly $\mathrm{I}_{\mathrm{PV}}$ diminished. Both the PV current and voltage are appeared in Figures 3 (a) and (b) correspondingly. Likewise, the voltage and current of the battery is appeared in Figures 3 (c) and 3 (d). Figures 4 and 5 show the inverter currents and voltages during the both steady state and transient state.

Stator currents inconsistent state are sinusoidal waveforms as appeared in the zoomed view portion of corresponding phase currents of Figure 5 and Figure 6 displays the results of the simulation of stator flux of five-phase IM drive using a $10 \mathrm{~N}$-m load under-rated and reduced-speed conditions. It can be noticed that, under both speeds, the drive is able to operate at constant flux conditions. Reference speed at the time of zero $\mathrm{sec}$ is $1430 \mathrm{rpm}$ and it is decreased to $1200 \mathrm{rpm}$ at the time of 1.5 seconds. It tends to be seen from Figure 7 that the genuine speed of the motor precisely tracks the reference speed. Till $1.5 \mathrm{~s}$, the reference speed is remains unchanged, but the source is changed, consistently detect the instabilities of speed momentarily. In such conditions, the drive is able to track the reference speed precisely under steady-state conditions. From Figure 8, power accessible since the $\mathrm{PV}$ is $5000 \mathrm{~W}$, from beginning moment to $\mathrm{t}=0.5$ second. So, the abundance in accessible power is deposited in battery up to the time 0.5 seconds. At the time $t=0.5 \mathrm{sec}$, PV current is diminished meanwhile irradiation is decreased, however the PV voltage stays constant, so power 
accessible from $\mathrm{PV}$ is diminished, which is inadequate to reach the load. From $\mathrm{t}=0.5 \mathrm{sec}$ to $\mathrm{t}=2 \mathrm{sec}$, inadequacy in power is exists from PV to satisfy the load demand, that inadequate power is acquired from the battery. The equivalent can be seen from the Figure 8.

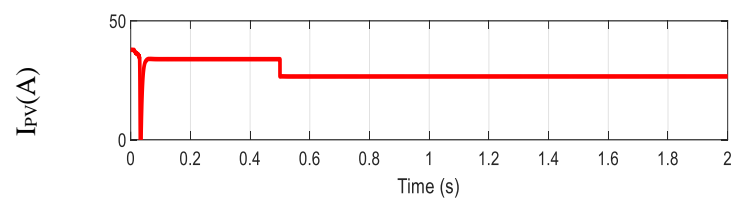

(a)

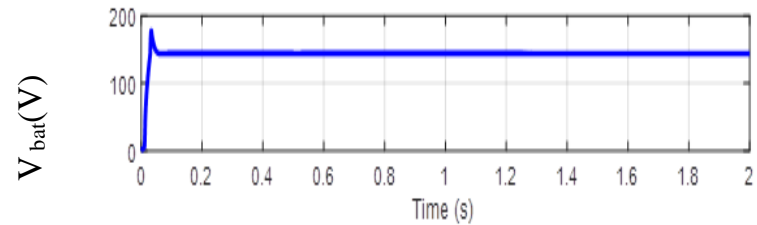

(c)

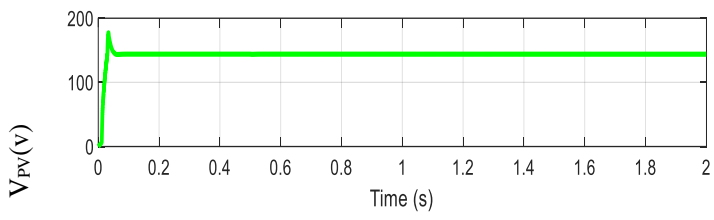

(b)

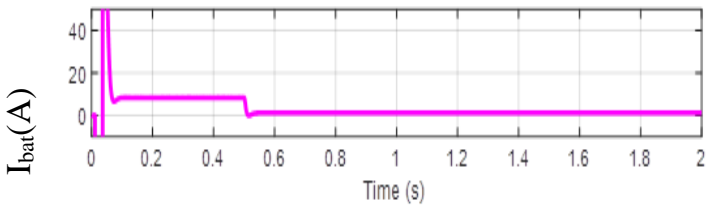

(d)

Figure 3. Simulation results of solar PV and battery parameters (a) solar PV current (b) solar PV voltage (c) battery voltage and (d) battery current
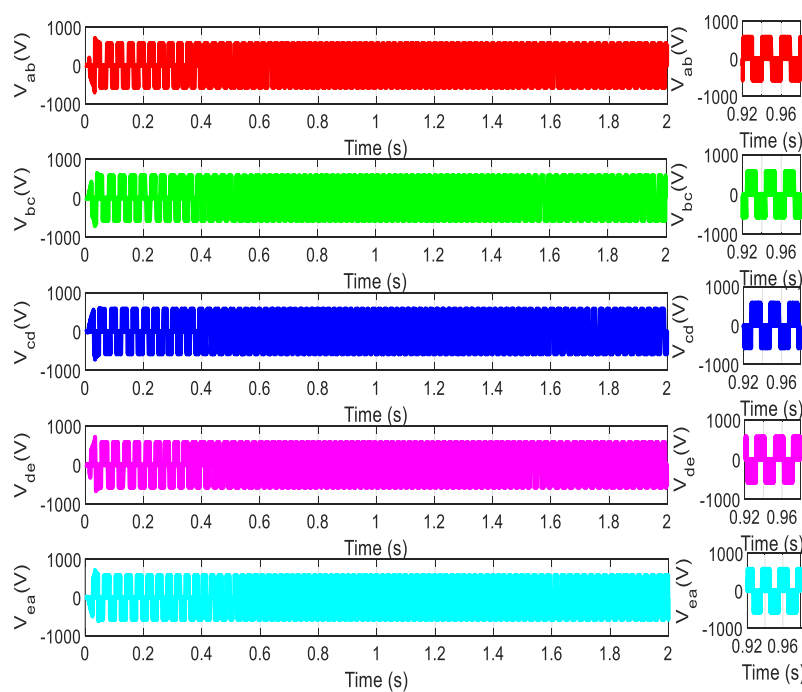

Figure 4. Line-line voltages

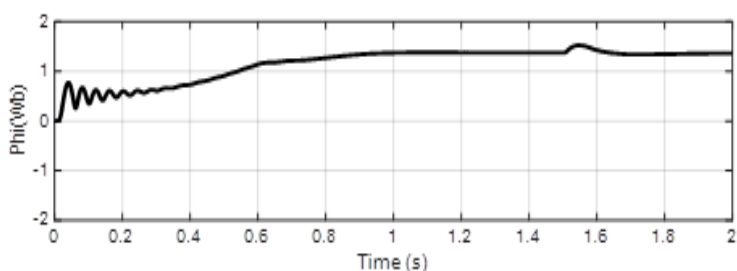

Figure 6. Stator flux of five-phase induction motor Time (s)
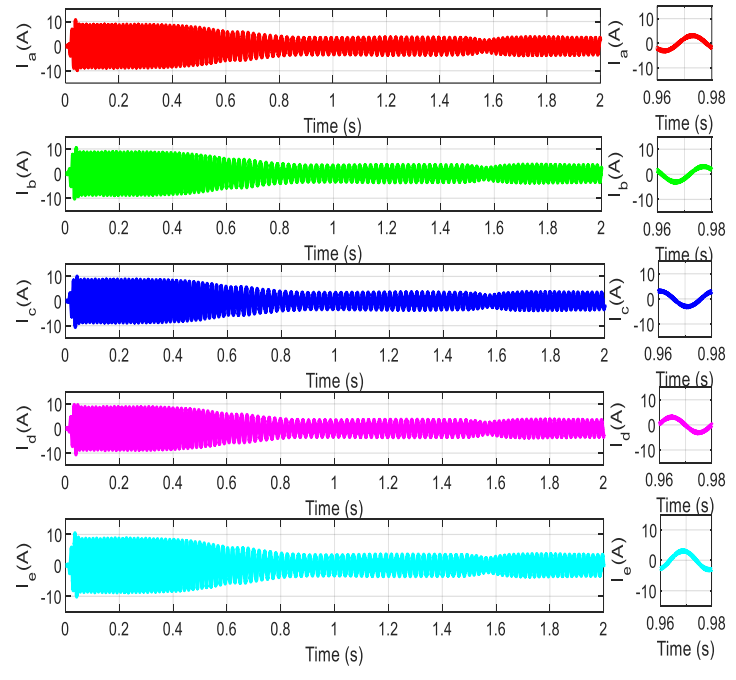

Figure 5. Stator currents of five-phase motor

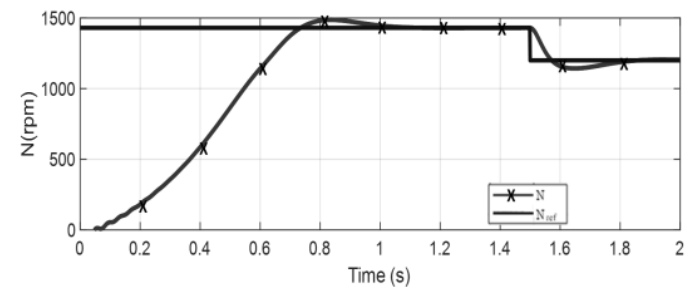

Figure 7. Actual and reference Speeds of motor 


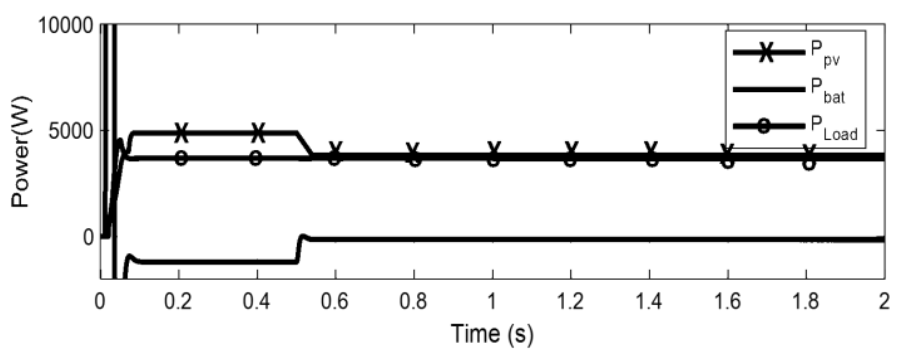

Figure 8. PV source power, battery power and load power in proposed system

\subsection{A comparative analysis of the proposed inverter \\ 3.1.1. Boost factors}

One more simulations set are achieved to examine the implementation of the beyond topologies. The considered parameters of simulations for comparative analysis are tabulated in the Table 2 . For the study of relative execution, boost factors are determined as the proportion of maximum D.C voltage in the circuit to the input D.C voltage for the necessary conversion of DC-AC.

Table 2. Simulation parameters for comparative analysis

\begin{tabular}{lc}
\hline \multicolumn{1}{c}{ Parameter } & Value \\
\hline Input DC voltage & $200 \mathrm{~V}$ \\
Switching frequency & $10 \mathrm{kHz}$ \\
Filter inductance & $250 \mu \mathrm{H}$ \\
Power & $3000 \mathrm{~W}$ \\
Output line voltage (RMS) & $350-600 \mathrm{~V}$ \\
Filter capacitance & $44 \mu \mathrm{F}$ \\
\hline
\end{tabular}

\subsubsection{Variation of duty cycle}

As stated previously, the adjustment in the impedance network setup, boost factors of every single topology possibly will vary from others. Hypothetically, the extreme boost factor of every single topology is immeasurable. Boost factors are essential for the conversion DC to AC from 1 to 1.75, i.e., while 200 V D.C is changed over $350 \mathrm{~V} \mathrm{AC}$ to $600 \mathrm{~V}$ AC (RMS line), are intended and illustrated in the Figure 9. From this Figure 9, it is evident that the projected inverter is capable to alter the input D.C into essential A.C with the necessity of a low boost factor.

Variations of duty cycle are intended as the variations in the middle of the maximum and minimum duty cycles essential for the conversion DC to AC in a definite variety. For the determination of contrast of various topologies, the maximum and minimum duty ratios are intended for the $200 \mathrm{~V}$ D.C to $600 \mathrm{~V}$ A.C conversion (RMS line) and $200 \mathrm{~V}$ D.C to $350 \mathrm{~V}$ AC conversion (line RMS) respectively. These values are introduced in a bar diagram, as appeared in Figure 10. From the bar diagram, it is evident that the variation of duty cycle range for the essential D.C to A.C conversion is huge on account of SL-qZSI; therefore, the duty cycle control is likely to be smooth on behalf of the introduced converter.

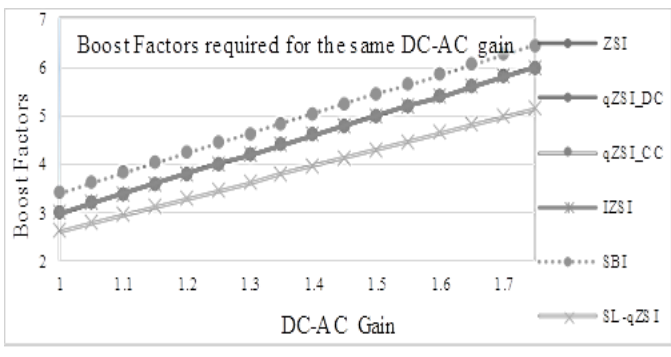

Figure 9. Boost factors

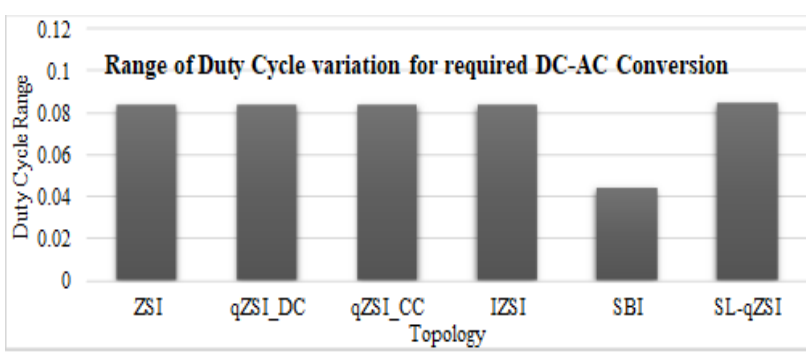

Figure 10. Representation of bar chart of variation of duty cycle 


\subsubsection{Peak DC-link voltages}

For the D.C to A.C conversion from 1 to 1.75 i.e., 200 V, D.C is altered from $350 \mathrm{~V}$ AC to $600 \mathrm{~V}$ A.C (RMS line). D.C-links of every single topology are diverse from others, as appeared in Figure 11. From this outcome, it is extremely evident that the values of D.C-link voltage are low on account of introduced converter when contrasted to others.

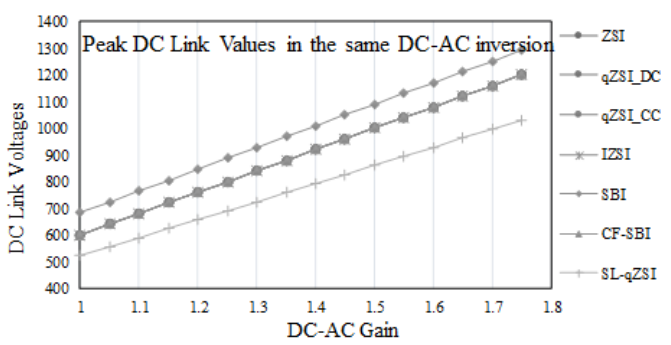

Figure 11. Peak DC link voltages in different topology

\subsubsection{Capacitor voltages and switching stresses}

Meanwhile capacitors utilized in different topologies are altered, total voltage stresses are determined for the sake of comparison in all capacitors. Here in Figure 12, the entire capacitor stresses are designed though $200 \mathrm{~V} \mathrm{DC}$ is changed over a range of A.C from $350 \mathrm{~V}$ to $600 \mathrm{~V}$ (RMS line). From Figure 12, it is evident that the stresses of capacitors are extreme low on account of the introduced inverter. Switching stresses in different topologies are illustrated in Figure 13. It is evident that from this figure, relatively the switching voltage stresses are low on account of the introduced inverter.

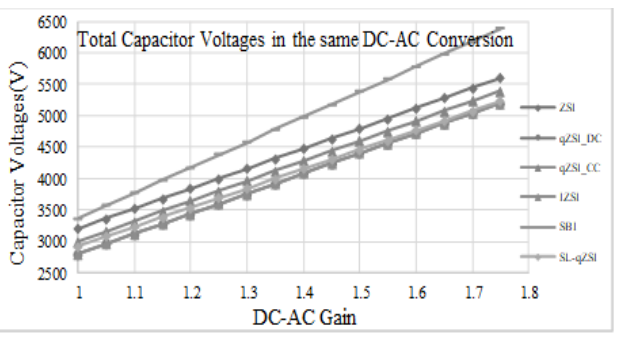

Figure 12. Total capacitor voltages in different topology

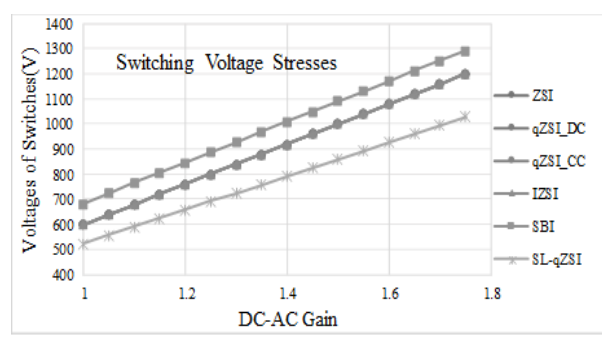

Figure 13. Switching voltage stresses in different topologies

\subsubsection{Passive components}

Capacitors and inductors for the existing and proposed topologies are intended for the various gains of DC to AC conversion. For the purpose of comparison, these are introduced as plots illustrated in Figures 14 and 15. These figures show that the essential inactive components to design the introduced converter are significantly fewer components than former topologies of 1-phase inverter.

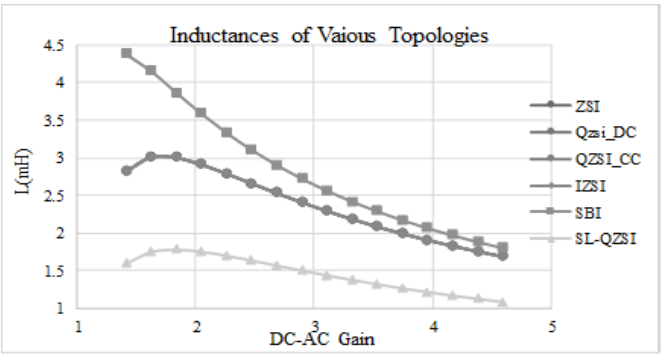

Figure 14. Values of inductance at different topologies (in $\mathrm{mH})$

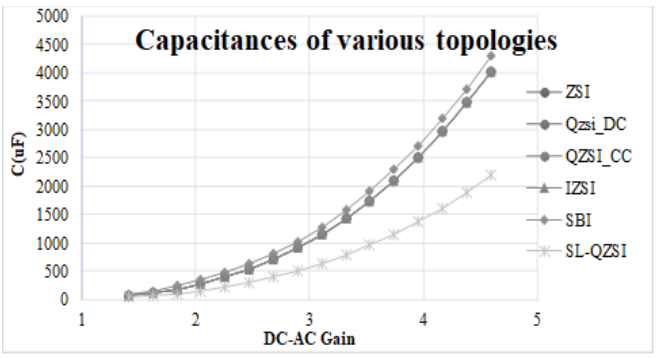

Figure 15. Capacitance values in various topologies (in $\mathrm{uF}$ ) 


\section{CONCLUSION}

A high performance, highly reliable, and greater efficient SL-qZSI fed five-phase IM drive is introduced in the paper. In contrast to the counterpart i.e., classical VSI fed 3-phase IM drive, the combination of SL-qZSI five-phase IM attains best reliability and efficiency. Various attributes of the fivephase IM drive system are investigated with SL-qZSI. Desired performance is accomplished by the suggested system, and it is verified using simulations with V/f control. The suggested system can be implemented in the systems where better efficiency and reliability are of more concern. Its agreement validates the simulation results.

\section{REFERENCES}

[1] A. Shawier, A. S. Abdel-Khalik, R. A. Hamdy, K. H. Ahmed and S. Ahmed, "Postfault Operation of Five-Phase Induction Machine with Minimum Total Losses Under Single Open-Phase Fault," in IEEE Access, vol. 8, pp. 208696-208706, 2020, doi: 10.1109/ACCESS.2020.3036904.

[2] B. A. Welchko, T. A. Lipo, T. M. Jahns and S. E. Schulz, "Fault tolerant three-phase AC motor drive topologies: a comparison of features, cost, and limitations," IEEE Trans. Power Electron., vol. 19, no. 4, pp. 1108-1116, 2004, doi: 10.1109/TPEL.2004.830074.

[3] E. Levi, "Multiphase Electric Machines for Variable-Speed Applications," IEEE Trans. Ind. Electron., vol. 55, no. 5, pp. 18931909, 2008, doi: 10.1109/TIE.2008.918488.

[4] E. Levi, R. Bojoi, F. Profumo, H. A. Toliyat and S. Williamson, "Multiphase induction motor drives - a technology status review," IET Electr. Power Appl., vol. 1, no. 4, pp. 489-516, 2007, doi: 10.1049/iet-epa:20060342.

[5] J. M. Apsley, S. Williamson, A.C. Smith and M. Barnes, "Induction motor performance as a function of phase number," IEE Proceedings Electric Power Applications, vol. 153, no. 6, pp.898-904, 2006, doi: 10.1049/ip-epa:20060091.

[6] L. de Lillo., "Multiphase Power Converter Drive for Fault-Tolerant Machine Development in Aerospace Applications," IEEE Trans. Ind.Electron., vol. 57, no. 2, pp. 575-583, 2010, doi: 10.1109/TIE.2009.2036026.

[7] Y. S. Babu and K. C. Sekhar, "Battery Assisted, PSO-BFOA based Single Stage PV Inverter fed Five Phase Induction Motor Drive for Green Boat Applications," Intelligent Systems and Computing, vol 910, pp. 227-240, 2020, doi: 10.1007/978-981-136095-4_17.

[8] S. M. Dabour, A. S. Abdel-Khalik, S. Ahmed and A. M. Massoud, "A new dual series-connected Nine-Switch Converter topology for a twelve-phase induction machine wind energy system," 2017 11th IEEE International Conference on Compatibility, Power Electronics and Power Engineering (CPE-POWERENG), 2017, pp. 139-144, doi: 10.1109/CPE.2017.7915159.

[9] G. K. Singh, "Multi-phase induction motor drive research - a survey," Electric Power Systems Research, vol. 61, no. 2, pp. 139147, 2002, doi: 10.1016/S0378-7796(02)00007-X.

[10] Y. Liu, H. Abu-Rub, B. Ge, F. Blaabjerg, O. Ellabban and P. C.g Loh, Impedance source power electronic converters, 1th ed, Hoboken, New Jersey: John Wiley \& Sons:, 2016.

[11] M. Shen, A. Joseph, J. Wang, F. Z. Peng and D. J. Adams, "Comparison of Traditional Inverters and Z -Source Inverter for Fuel Cell Vehicles," in IEEE Transactions on Power Electronics, vol. 22, no. 4, pp. 1453-1463, July 2007, doi: 10.1109/TPEL.2007.900505.

[12] Fang Zheng Peng et al., "Z-source inverter for motor drives," in IEEE Transactions on Power Electronics, vol. 20, no. 4, pp. 857863, July 2005, doi: 10.1109/TPEL.2005.850938.

[13] Fang Zheng Peng, "Z-source inverter," in IEEE Transactions on Industry Applications, vol. 39, no. 2, pp. 504-510, March-April 2003, doi: 10.1109/TIA.2003.808920.

[14] S. Rahman et al., "Design and Implementation of Cascaded Multilevel qZSI Powered Single-Phase Induction Motor for Isolated Grid Water Pump Application,” in IEEE Transactions on Industry Applications, vol. 56, no. 2, pp. 1907-1917, March-April 2020, doi: 10.1109/TIA.2019.2959734.

[15] S. M. J. Rastegar Fatemi, J. Soltani, N. R. Abjadi and G. R. Arab Markadeh, "Space-vector pulse-width modulation of a Z-source six-phase inverter with neural network classification," IET Power Electronics, vol. 5, no. 9, pp. 1956 - 1967,2012 , doi: 10.1049/iet-pel.2011.0426.

[16] J. Anderson and F. Z. Peng, "Four quasi-Z-Source inverters," 2008 IEEE Power Electronics Specialists Conference, 2008, pp. 2743-2749, doi: 10.1109/PESC.2008.4592360.

[17] Y. Tang, S. Xie, C. Zhang and Z. Xu, "Improved Z-Source Inverter With Reduced Z-Source Capacitor Voltage Stress and SoftStart Capability," in IEEE Transactions on Power Electronics, vol. 24, no. 2, pp. 409-415, Feb. 2009, doi: 10.1109/TPEL.2008.2006173.

[18] M. Nguyen, Y. Jung and Y. Lim, "Single-Phase AC-AC Converter Based on Quasi-Z-Source Topology," in IEEE Transactions on Power Electronics, vol. 25, no. 8, pp. 2200-2210, Aug. 2010, doi: 10.1109/TPEL.2010.2042618.

[19] M. Zhu, K. Yu and F. L. Luo, "Switched Inductor Z-Source Inverter," in IEEE Transactions on Power Electronics, vol. 25, no. 8, pp. 2150-2158, Aug. 2010, doi: 10.1109/TPEL.2010.2046676.

[20] C. J. Gajanayake, F. L. Luo, H. B. Gooi, P. L. So and L. K. Siow, "Extended-Boost ZZ-Source Inverters," in IEEE Transactions on Power Electronics, vol. 25, no. 10, pp. 2642-2652, Oct. 2010, doi: 10.1109/TPEL.2010.2050908.

[21] W. Qian, F. Z. Peng and H. Cha, "Trans-Z-Source Inverters," in IEEE Transactions on Power Electronics, vol. 26, no. 12, pp. 3453-3463, Dec. 2011, doi: 10.1109/TPEL.2011.2122309.

[22] B. Axelrod, Y. Berkovich and A. Ioinovici, "Switched-Capacitor/Switched-Inductor Structures for Getting Transformerless Hybrid DC-DC PWM Converters," in IEEE Transactions on Circuits and Systems I: Regular Papers, vol. 55, no. 2, pp. 687-696, March 2008, doi: 10.1109/TCSI.2008.916403.

[23] M. Prudente, L. L. Pfitscher, G. Emmendoerfer, E. F. Romaneli and R. Gules, "Voltage Multiplier Cells Applied to Non-Isolated DC-DC Converters," in IEEE Transactions on Power Electronics, vol. 23, no. 2, pp. 871-887, March 2008, doi: 10.1109/TPEL.2007.915762.

[24] M. -K. Nguyen, Y. -C. Lim and G. -B. Cho, "Switched-Inductor Quasi-Z-Source Inverter," in IEEE Transactions on Power Electronics, vol. 26, no. 11, pp. 3183-3191, Nov. 2011, doi: 10.1109/TPEL.2011.2141153.

[25] O. Ellabban and H. Abu-Rub, "Field oriented control of a five phase induction motor fey by a Z-source inverter," 2013 IEEE International Conference on Industrial Technology (ICIT), 2013, pp. 1624-1629, doi: 10.1109/ICIT.2013.6505916. 
[26] R. A. Hammad, S. M. Dabour and E. M. Rashad, "Performance of a six-phase induction motor fed from a Z-source inverter under faulty conditions," 2017 Nineteenth International Middle East Power Systems Conference (MEPCON), 2017, pp. 1333-1338, doi: 10.1109/MEPCON.2017.8301355.

[27] M. Morawiec, P. Strankowski, A. Lewicki, J. Guziński and F. Wilczyński, "Feedback Control of Multiphase Induction Machines with Backstepping Technique," in IEEE Transactions on Industrial Electronics, vol. 67, no. 6, pp. 4305-4314, June 2020, doi: 10.1109/TIE.2019.2931236.

\section{BIOGRAPHIES OF AUTHORS}

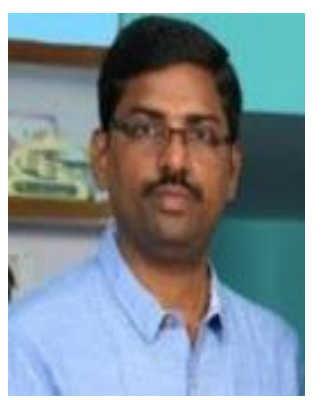

Yaramasu Suri Babu (D) 81 SC P was born in 1975 in Andhra Pradesh, India. He received B.Tech degree in Electrical \& Electronics Engineering from J.N.T.U.H, Hyderabad and M. Tech with Power \& Industrial Drives from J.N.T.U.A, Anathapur, India. He is Research Scholar in Department of Electrical \& Electronics Engineering, ANU College of Engineering and Technology, Acharya Nagarjuna University. He is having 15 years of teaching experience. He is currently working as Assistant Professor in the Department of Electrical \& Electronics Engineering, R.V.R \& J.C. College of Engineering, Guntur, India. His Research interests are in the areas of Power Electronics, Industrial Drives \& Renewable Energies. He can be contacted at email: ysuribabu@gmail.com.

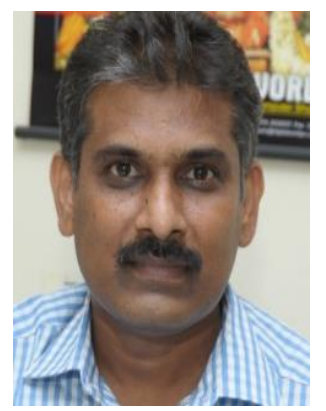

Koritala Chandra Sekhar (iD SC SC was born in 1968 in Andhra Pradesh, India. He received B. Tech degree in Electrical \& Electronics Engineering from V.R. Siddartha Engineering College, Vijayawada, India in 1991 and M.Tech with Electrical Machines \& Industrial Drives from Regional Engineering College, Warangal, India in 1994. He Received the Ph.D degree from the J.N.T.U.H, Hyderabad, India in 2008. He is having 24 years of teaching and research experience. He is currently working as Professor \& Head in the Department of Electrical \& Electronics Engineering, R.V.R \& J.C. College of Engineering Guntur, India. His Research interests are in the areas of Power Electronics, Industrial Drives \& FACTS Controllers. He can be contacted at email: cskoritala@gmail.com. 